\title{
木質パネル研究会・生物劣化研究会 合同講演会に参加して
}

\section{はじめに}

2010年 3 月19日に木質パネル研究会・生物劣化 研究会合同講演会が，宮崎市の宮崎観光ホテルに おいて, 第60回日本木材学会大会の最終日に開催 された。

本講演会は, 木質パネル研究会と生物劣化研究 会の合同で，足立幸司氏（東京大学）の総合司会 の下,「木質パネルの耐久性〜生物劣化と接着劣化 の両面からのアプローチ〜」というテーマで行わ れた。講演内容は,「木質パネル第二次耐久性プロ ジェクトの概要と進渉」，「木質パネルにおける促 進劣化処理と屋外暴露の関係」, 「保存処理合板 . LVL の耐久性評価」，「腐朽した木質面材の釬接合 性能」という 4 題で, 大変興味深いものであった。 本稿では, 講演の概要を, 講演及び講演要旨を元 に紹介するが，筆者の筆力不足の為に説明しきれ ていないところはご容赦いただきたい。

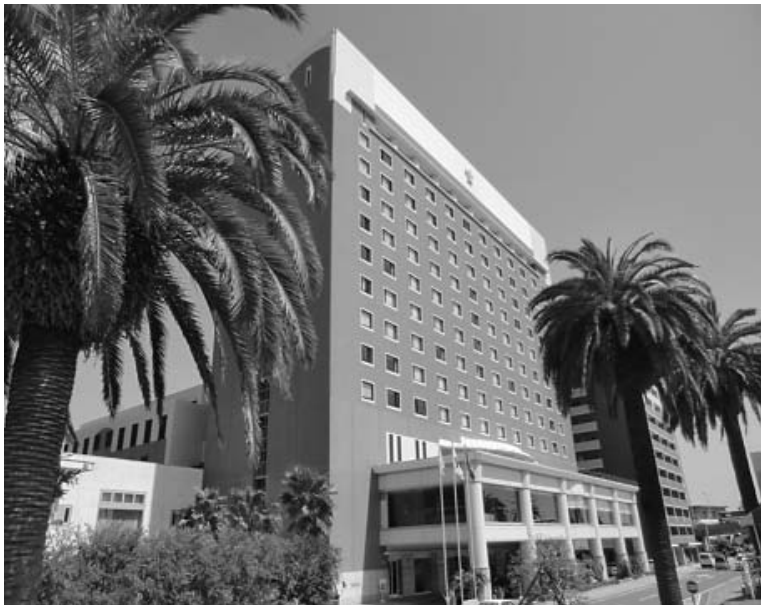

図1会場となった宮崎観光ホテル

\section{1.「木質パネル第二次耐久性プロジェク トの概要と進渉」}

岩手大学農学部 関野 登氏

日本木材学会木質パネル研究会によって，2003 年に開始された各種木質パネルに関する耐久性評 価プロジェクトの概要および，現在の進渉状況に ついて講演された。

本プロジェクトは，(1)構造用に使用可能な国産 ボード類の耐久性を, 構造用合板や OSB を含めた 木質パネル全体から位置づけること, (2)屋外暴露 試験 - 屋内暴露試験 - 促進劣化処理試験の試験方 法間の時間換算を行い, 実使用環境下での耐用年 数の推定手法を開発することを目的に, 全国規模 で屋外暴露試験, 各種屋内暴露試験, 促進劣化試 験などを実施している。

本プロジェクトを第二次と位置付けているが, これは木質パネル研究会の前身である木質ボード 懇話会が，1991年～2002年度まで「木質パネル耐 久性評価プロジェクト」を実施したことによる。 当時，合板以外の木質パネルに関する屋外暴露試 験データがそしかったことから, 当時の市販パネ ルである, 南洋材合板, OSB, パーティクルボード (PB)，MDF，ハードボード，木片セメント板など を対象に屋外暴露，促進劣化試験を実施し，耐久 性の評価方法に関する知見や暴露試験の問題点な どが整理された。その後，南洋樹合板から針葉樹 合板への転換, PB の解体材由来原料の使用増加, 非ホルムアルデヒド系接着剂 (MDI) の使用などの 原材料事情の変化や，木質パネルの使用量増加に 伴う耐久性予測の重要性や需要増大を背景に, 構

＊住化エンビロサイエンス株式会社 
造用パネルの性能として重要な釘接合性能などの 評価を追加し，第二次プロジェクトとして開始さ れた。

プロジェクトでは，供試試料に針葉樹合板, OSB，PB，MDF の構造用を基本とする市販木質パ ネルを対象に, 屋外暴露試験, 屋内暴露試験, そ して実験室的な促進劣化試験を全国 9 機関，総勢 約20名で各種の課題を分担し，実施している。

屋外暴露試験は全国 8 試験地（旭川，盛岡，能 代,つくば, 岡山 (北部), 岡山（瀬戸内), 静岡, 都城）で2004年に開始され，定期的に材面観察や 生物劣化の発生状況, 重量損失, 厚さ膨張, 曲げ 性能,はく離強度などの基礎物性を調査している。 盛岡, つくば, 岡山（瀬戸内）, 都城の 4 試験地で は釬接合性能に関する評価も併せて実施されてい る。屋内暴露試験は, 恒温恒湿室内 $\left(20^{\circ} \mathrm{C}: 60 \%\right.$ $\mathrm{RH})$ ，モデルハウス床下, 実験ハウスへの施工, 高 湿度下暴露 $\left(20^{\circ} \mathrm{C}: 90 \% \mathrm{RH}\right)$, 乾湿繰り返 $\left(20^{\circ} \mathrm{C}: 45 \% \mathrm{RH}\right.$ と $90 \% \mathrm{RH}$ で, 3 カ月ごとの反復 $)$ の 5 つの水分レベル下で試験を実施し, 屋外暴露 と同様に, 曲げ性能, はく離強度, 釬接合性能(釘 一面せん断挙動，釬側面抵抗，釷頭貫通抵抗）の 劣化を調査している。実験室的な促進劣化試験は JIS-A，JIS-B 処理を基本として乾燥や凍結を加え た試験，V313処理，およびASTM 6 サイクル処理 による釷接合性能（釷側面抵抗，釬頭貫通抵抗， 釘一面せん断性能）の劣化試験を実施している。

本講演では結果の一例として，5年間経過時点 での, 各種パネルの曲げ強度 (MOR) 劣化につい て説明する。また，プロジェクトの進渉状況は， 日本木材加工技術協会木質ボードシンポジウムの 要旨集に毎年揭載されてきており，これらの報告 も併せてご参照いただきたい。

まず，屋外暴露試験の結果では，パネル種類間 でMOR 劣化の進行は大きく異なった。盛岡での 暴露では, MDF，特類合板 ( $\mathrm{PF}$ 樹脂), PB (MDI 樹脂）が暴露 5 年目で MOR 残存率 $50 \%$ 以上を保 持し，一方，OSB や PB は残存率40\%以下となっ た。また，アスペン OSB の MOR 残存率を暴露地 域間で比較すると, 降水量の多い静岡や都城では 暴露初期から残存率低下が大きく, 接着劣化とと もに生物劣化の影響が示唆された。屋外暴露では 乾湿が繰り返されるので, これにより, 熱圧成形
されたエレメントが吸水による膨張と乾燥による 収縮を繰り返し, 接着点が破壊され, 変形拘束を 免れたエレメントはより厚さ膨張が生じ易くな り, 接着点の破壊が更に進行する。その結果, 厚 さ脵張の進行につれて強度低下が進行する。さら に, パネルの厚さ膨張に伴い, 生物劣化を引き起 こす菌類がパネル中に侵入しやすくなると考えら れ, 生物劣化による強度劣化が進行する。このよ うな生物劣化を引き起こさないためにも，木質パ ネルの厚さ膨張の抑制が重要である。

屋外暴露試験では劣化の進行は気象条件に依存 し，その結果を気象条件が異なる地域で利用する ことは難しいという弱点も存在する。本プロジェ クトでは，同一ロットの材料を様々な気象条件で 暴露して地域差を検討し, 各試験地の釘側面抵抗 残存率などのパネル劣化指標と, 暴露試験地の気 象データから, 地域差を排除した耐久性予測の普 遍モデルの構築を目指している。

これまでに，比較的大きな強度低下が現れたア スペン OSB, PB（PF）の全物性と, MDF の一部の 物性で試算を実施し, 釘側面抵抗残存率と気温と 降水量, 相対湿度などの気象因子の組合せで, 地 域差を排除できる劣化指標が算出されている。劣 化の進行の遅い木質パネルの暴露デー夕を継続し て取得しており, 今後, 各種パネルの特性を加味 した地域差を排除した耐久性予測モデルの確立が 期待される。

\section{2.「木質パネルにおける促進劣化処理と 屋外暴露の関係」}

静岡大学農学部 小島陽一氏

OSB，PB，MDF などの木質ボードは, 小径木や 端材・残材，リサイクル材等から製造されるため, 木質資源の総合利用の観点から, 木質資源の有効 利用の一翼を担う材料として期待され, 構造用途 への需要拡大が望まれる。しかし, 構造用途での 実績にそしいため, その接着耐久性等の強度低下 が不安視され，需要拡大を阻む一要因となってお り, 耐久性の評価と, その有効な評価方法が求め られている。

耐久性評価には, 屋外・屋内暴露試験と, 実験 室的な促進劣化試験が考えられるが, 屋外暴露試 験は, 期間, 地域差, 再現性, 実使用環境と暴露 
環境の差という，科学的な手法としては多くの弱 点を持った試験法である。一方, 実験室的な促進 劣化試験は, 短期評価が可能で, 処理環境を人為 的に設定できる為，実用的な評価手法として不可 欠である。しかし, 実使用時の劣化機構の差異と いう問題があり，この劣化機構が異なれば，耐久 性の過大評価や過小評価を招く恐れがある。

本プロジェクトでは，日本及び欧州・北米で規 格化された促進劣化処理試験と屋外暴露試験で各 種木質パネルの耐久性を評価し，各方法による相 対的な促進強度を把握し, さらに屋外暴露試験の 結果と関連づけた促進劣化試験の強弱や妥当性を 評価し，有用な評価方法を得ることを目的として いる。

本講演では, 各種促進劣化処理及び, 静岡での 5 年間の屋外暴露試験による各種パネルの厚さ膨 張率と内部結合力（IB）の変化と，それらを指標 とした劣化強度の相関について報告された。ま ず，5種類の促進劣化処理試験（JIS-B 処理, APAD- 1 処理, V313処理, ASTM 6 サイクル処理, VPSD 法）を参考に，その処理回数の違いによる， $\mathrm{PB}, \mathrm{MDF}, \mathrm{OSB}$, 合板の各種パネルの厚さ変化率 と IB を測定した。これらの促進劣化処理試験で は，パネルに使用される接着剂，構成エレメント の種類により劣化の程度に大きな差が生じた。厚 さ膨張率は, 処理回数の増加とともに厚さ膨張率 が増加する PB や OSB などのパターンと, 初期の 処理で厚さ膨張率が増加し，その後の処理ではほ とんど増加しない合板, MDF のようなパターンが 確認された。IB 残存率は, 合板以外は処理方法に 関わらず, 処理回数の増加により IB が指数関数的 に低下寸る傾向が認められた。また，パネルの種 類に関係なく, 厚さ膨張率と IB 残存率には相関関 係が見られた。

この各促進劣化試験により得られた厚さ膨張率 と IB 残存率を指標に, 各規格の規定処理回数に基 づいて劣化強度を比較すると, ASTM 6 サイクル, JIS-B, V313, APAD- 1 の順に促進処理が厳しいこ とを明らかにした。

屋外暴露では, MDFを除く全てのパネルで, 亀 裂や反り，端面の空洞化が観察された。全てのパ ネルで経年による重量減少も確認されたが，アス ペン OSB では生物劣化の影響による端部の脱落
等により $30 \%$ 以上の大きな重量減少を示した。ま た，アスペンの OSB と PB（PF）では, 20\%以上 の厚さ膨張が観察され, IB も5 年間で残存率が 10\%以下に低下した。MDFでは, 重量変化, 厚さ 膨張率ともに 5 年間で数\%程度のわずかな変化で あり，IB 残存率もほぼ100\%を維持していた。

上記の促進劣化処理及び静岡での屋外暴露で得 られた, 各パネルの厚さ膨張率と, IB 残存率から 各試験の劣化強度を比較し, 各種促進劣化処理が 屋外暴露のどの程度の負荷に相当するかを推算し て示した。今後, 全国各地の屋外暴露データと, 促進劣化処理との対応を更に検討し, より確実な 耐久性評価方法の確立が期待される。また, 非破 壊試験方法（振動法）によるパネル内部の劣化メ カニズムの評価検討や, 世界各国の気象条件によ る屋外暴露デー夕の採取が今後の課題として述べ られた。

\section{3.「保存処理合板・LVL の耐久性評価」}

独立行政法人森林総合研究所 桃原郁夫氏 土台・柱・筋交い等軸材を中心として構成され た既存在来木造では, 構造躯体の劣化防止を図る 場合, 軸材に防腐・防蟻措置をすれば良かったが, 近年の在来木造では土台や柱を合板等の面材で一 体化して構造躯体とする工法が主流であるため, 構造躯体の劣化防止を図る際は, 軸材の劣化防止 に加え面材の防腐・防蟻措置を考慮する必要があ る。

製材では, 防腐・防蟻措置として, JAS に使用区 分や，それに対応する各種木材保存剂の種類とそ の吸収量との基準が定められている。一方, 面材 については一部 AQ で基準が定められているが, JAS 規格にはその基準がない。そこで, 森林総合研 究所や北海道立林産試験場が中心となり, 保存処 理合板の JAS 規格制定に必要なデー夕を整備し てきた。本講演では, その結果の一部について説 明された。

合板 · LVL の保存処理の方法として, (1)接着剂 混入処理（合板を製造する際に使用する接着剂に 木材保存剤を混入する処理法), (2)単板加圧注入処 理（単板に木材保存剂を加圧しながら注入した後 に貼り合わせる処理法), (3)製板加圧注入処理（通 常の方法で製造した合板に後から木材保存剤を加 
圧注入する処理法）がある。

これらの保存処理合板の耐久性の最適な評価方 法を確立するために，無処理合板・LVLを用い て, 而朽性および而蟻性の試験方法の検討を実施 した。木材腐朽菌に対する耐朽性試験では, 樹種 や，その試験体を設置する向きによる影響が確認 された。単板の樹種による耐朽性への影響は，本 条件ではトドマッ合板, カラマツ合板, スギ合板 の順に高い耐朽性を示し，スギが最も腐朽されや すかった。また，合板表面を培地と平行に置いた 試験体では，合板切断面を培地と接するように設 置した試験体より低い質量減少率を示し, 菌糸が 試験体の上部にまで到達しない試験体が観察され た。この結果から，スギ合板を用い，その合板の 繊維方向が培地面と接するように設置することが 望ましい事が分かった。

一方, 耐蟻性試験では, 試験体の設置の仕方に よる影響は見られなかったが，耐朽性試験と同様 に単板樹種による影響が見られ，トドマツ合板， カラマツ合板，スギ合板の順に高い耐蟻牲を示し た。

また，耐朽性の低かったスギを用いて，その辺 材と心材の違いによる耐朽性を評価した。スギの 辺材または心材で製造した LVLをカワラタケま たはオオウズラタケに暴露したところ, 辺材 LVL をカワラタケに暴露した場合に大きな質量減少率 を示したが，それ以外の条件では質量減少率は 3 \%以下であった。

これらの評価結果をもとに試験方法を設定し， 保存処理合板・LVL で耐久性を評価した。まず, 接着剂混入処理で製造したイミダクロプリドおよ びシプロコナゾール含有スギ辺材 LVL で耐朽性 評価を実施した。接着郕混入処理 LVLを切り出 し，その瀻維方向を培地と垂直にしてカワラタケ またはオオウズラタケに暴露したところ，いずれ も防腐性能試験の性能基準を満足した。また, 同 じ LVL の別の試験体をファンガスセラーに設置 したところ, 試験開始 9 ケ月で被害度の上昇が観 察されたが，無処理と比較し 3 倍程度の耐用年数 が期待される結果となった。

次に, 単板加圧注入処理, 製板加圧注入処理合 板および接着剂混入処理スギ合板の耐久性・耐蟻 性を評価した。加圧注入処理剂の木材保存剤は
CUAZ, ACQ, AAC, AZN の 4 種でいずれも K 3 相当とした。また, 接着剤混入処理は K 3 相当の 2 種を用いた。室内防腐性能試験掞よび室内防蟻 性能試験の結果, いずれの試料も性能基準を満足 した。また，ファンガスセラー試験では, 試験 1 年後で無処理スギ辺材は質量減少率がおよそ30\% に達したのに対し, 加圧注入処理で製造した各種 合板の質量減少率の平均值はいずれも $3 \%$ 以下で あった。一方，メランチ合板に同様の処理を施し た試験体の中には基準を満足しないものもあっ た。針葉樹合板と広葉樹合板とでは, 組織構造が 異なるため, 薬剤の浸潤性などに差異が生じる可 能性もあり, 同じ耐朽性能を出すためには, 薬剤 の仕込み量を変えるなどの工夫が必要だと考えら れた。

これらの試験結果から, 保存処理木質パネルに 対する, 実験者間による誤差の少ない試験方法の 確立など，今後の展開が非常に期待される。

\section{4.「腐朽した木質面材の釘接合性能」}

北海道立林産試験場 戸田正彦氏 木造住宅において, その耐震強度は柱と土台の 接合部の強度が重要となる。この接合部の性能が, 建物全体の強度に影響する。また, 耐力部材とし て合板などの木質面材を用いた場合にも，面材全 体のせん断剛性よりも, 釘の接合部の性能が重要 となる。これらの接合部に対する, 腐朽の影響を 把握しておくことは，住宅の耐震強度を把握する 上で大変重要な要素となる。本講演では, これま でに得られた腐朽による木質面材の釬接合性能へ の影響評価結果を中心に報告された。

釬接合部のせん断耐力の推定方法として, ヨー ロッパ型降伏理論が知られている。これは木材中 の釷のめり込み降伏の性状をもとに，その降伏耐 力を算定するものである。土台と柱を金物で固定 する場合を想定し, 主材である木材と鋼板の側材 を釘で固定する場合は, 鋼板と釘の強度がわかれ ば, 主材の縦圧縮強度から, 接合部の耐力が推定 できるというものである。本理論で，腐朽した釘 接合部の耐久性推定が可能であるかを確認する為 に，主材に鋼板製の側材を釘で固定し，その接合 部を強制的に腐朽させた後にせん断試験により耐 力測定を実施した。その結果, 腐朽の進行により, 
釘接合部の強度低下が確認され，60日程度の腐朽 処理で，健全材と比較して少ない荷重で変形する ことが分かった。また，主材の縦圧縮強度は，腐 朽処理期間が経過するにつれて強度低下が確認さ れ，主材の質量減少率の増加に伴い圧縮強度が指 数関数的に低下寸ることが確認された。この主材 の縦圧縮強度から，接合部のせん断降伏耐力を試 算した結果，先のせん断試験による実験值と概ね 一致する傾向が確認され，腐朽した釬接合性能の 評価にも適用できる事を確認した。

一方, 耐力壁などを柱に固定する場合を想定し， 鋼板の代わりに合板などの木質面材を釷で固定し た場合にも，ヨーロッパ型降伏理論で同様に接合 部の耐力を推定することが可能であるかを確認し た。木質面材の劣化の影響のみを確認する為に， 面材を固定する主材は防腐処理を実施し，ここに 木質面材を釘で直接接合した。これに，腐朽処理 を行った後に，せん断耐力試験を実施した。面材 には，針葉樹合板，ラワン合板，MDFを用いた。 その結果，鋼板を釷で固定した時と同様に，腐朽 の進行に伴い，せん断耐力の低下が確認された。 また, 同じ針葉樹合板でも, 単板の樹種構成や厚 さ構成などで強度低下に差異が生じ, ラワン合板 より針葉樹合板が腐朽しやすい傾向が確認され た。

この試験では，主材は防腐処理を実施している が，実際には少なからず腐朽し，また含水率が増 加したことで, 強度への影響が懸念された。この ため，木質面材自体の耐力を推定するには，木材 の圧縮強度と木質パネルの木質側面抵抗を各々把 握する必要があり, 主材の縦圧縮強度と側材の木 質面材の側面抵抗を測定した。この測定結果から， ヨーロッパ型降伏理論によりせん断耐力を試算を した結果，木質面材との接合部のせん断耐力実験 值と一致する傾向が確認された。また，側板に無
処理合板を用いた場合と比較して, 防腐合板や MDF を用いた場合では, 耐久性が向上することが 分かった。

今後の課題として，木質面材を用いた場合に懸 念される主材が健全で側材が劣化している場合 に，接合部で釬頭が面材を貫通破壊する破壊形態 への対応が述べられた。この破壊形態は, ヨーロ ッパ型降伏理論では推定ができないため, 釷頭貫 通試験のデータが必要であり, 今後木質パネルで 評価を実施していくとのことであった。また，現 在は破壊試験による残存強度の推定を実施してい るが, 非破壊手法による現場での木造住宅の劣化 診断を検討している。一例として，側材が鋼板の 場合は，鋼製のピンをバネの力で打ち込むピロデ インのピンの打ち込み深さから, 木材の残存強度 （縦圧縮強度）を推定することが可能であり,これ により釘接合部の耐久力が推定できる。側材が木 質パネルの場合でも, 非破壊での強度測定が可能 となれば, 接合部の耐力強度の推定が可能となり, 木造住宅の劣化診断の精度向上が期待できること から，その測定手法の開発が期待される。

\section{おわりに}

今回, 初めて木質パネル研究会と生物劣化研究 会の合同で研究会を実施されたとのことであった が, 学会等でも異なるセクションで発表されるこ とが多い内容を, 一堂に会して抨聴できる機会で あり，その両者の関係性の重要さを改めて認識す ることができた。本講演会をきっかけに, 両分野 の交流が進み, 木質パネルの劣化過程の解明や, 物理的・生物的な耐久性評価技術の向上により, 今後の木質パネルの利用拡大や高性能な木質製品 の開発，さらには素材としての木材の利用拡大一 とつながる事が期待される。

(2010. 4 .24受付) 